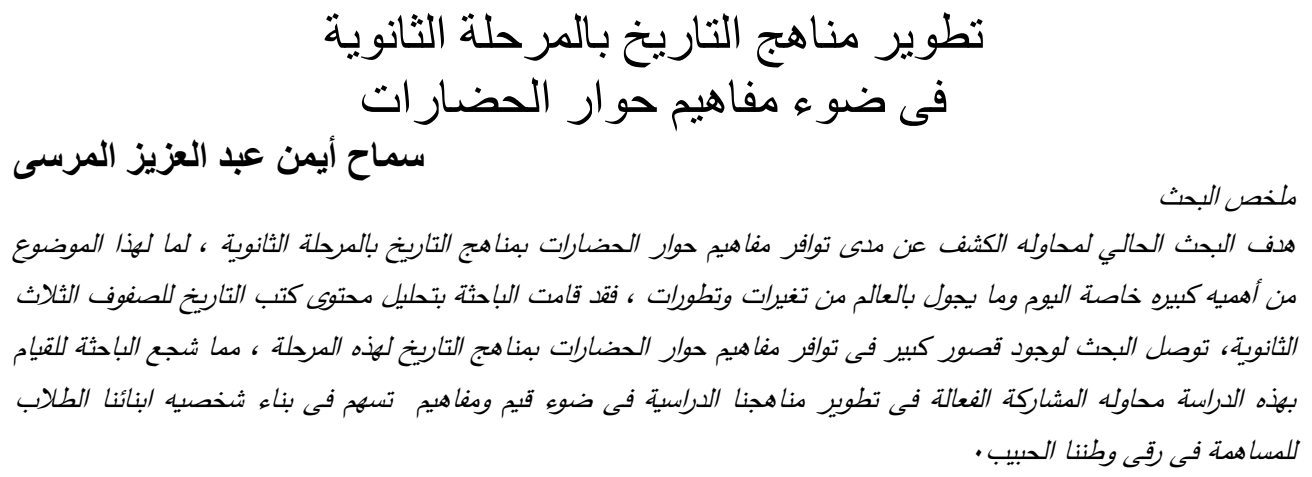

\title{
Abstract:
}

The current research aimed at attempting to detect the availability of the dialogue of civilizations concepts curriculum history secondary stage, as this subject has a great importance especially today, and what is happening in the world of changes and developments, the researcher has analyzes the content of history textbooks for the three grades of secondary school, the research found a significant deficiency in the availability of the dialogue of civilizations concepts in the history curriculum for this stage, which encouraged the researcher to carry out this study is an attempt effective participation in the development of our curriculum in the light of the values and concepts that contribute to build the character of our student to contribute to the advancement of our beloved country.

The research sample:

the research sample consists of 30 students from the second grade students at secondary stage.

The use of the following tools:

- List of concepts including the concepts of dialogue of civilizations (prepared by the researcher)

- a proposal imagination to the development of secondary school history curriculum in the light of the dialogue of civilizations concepts

- Educational unit of the proposed concept to be applied to the second grade secondary students in the light of the dialogue of civilizations concepts

- Achievement test ( prepared the researcher) to identify the effectiveness of upgraded unit in the light of the dialogue of civilizations concepts

\section{Research results:}

This current research resulted on the presence of highly effective for the upgraded unit and led to the development of the dialogue of civilizations concepts for the second secondary students.

\section{The current research recommend the following :}

Develop the history curriculum continuous row of follow through all that is new on the global arena in the light of the dialogue of civilizations concepts, and work to instill the values and concepts of dialogue in the hearts of different educational stages student to prepare a citizen capable of managing a positive and effective dialogue with others who are different civilized.

$$
\begin{aligned}
& \text { لتضرب مثالا فعالا في امكانيه الاتصال بين } \\
& \text { الحضارات عبر الأزمنة المختلفة . } \\
& \text { قال تعالى " يَاأَيْهَا النَّاسُ إنَّا خَلَقْنَاكُمْ مِنْ ذَكَرِ }
\end{aligned}
$$

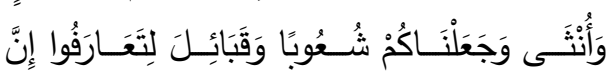

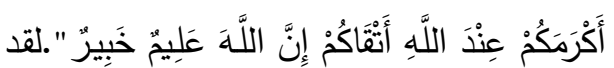

$$
\begin{aligned}
& \text { خلق الله سبحانه وتعالى الناس جميعا ينتمون }
\end{aligned}
$$

$$
\text { الإطار النظري للبحث : }
$$$$
\text { أساسي على الحضارات التي سبقتها ، فهي إما }
$$

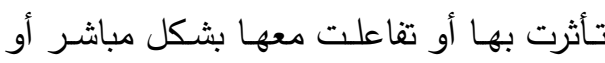$$
\text { غير مباشر فأصبح هناك حضـارة جديدة تقوم }
$$$$
\text { علـى دعامـات مـن الحضــارة التـي سـبقتها، }
$$$$
\text { لتوضـح مـدى تقاعلهـا وتأثرهـا بتلك الحضــارة }
$$ 
بأسـره شـرقه وغربـه شماله وجنوبـه (وليد عبد

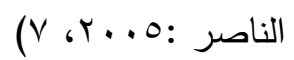
على الرغم من ذلك فلم تكن أراء فوكو يامـا

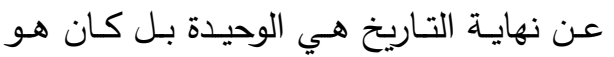

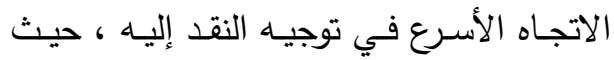
أعقبتــه نظريــهـ "Samuel.Huntington" العـالم السياسي الامريكى ،والتي جاءت نظريته لتؤكد

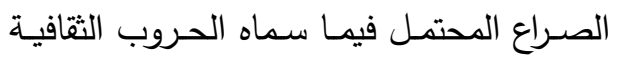

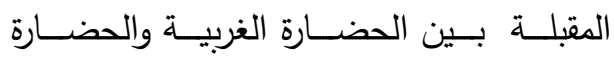
الاسـلاميه والحضـــارة الكونفوشـيه بمـا أســاه "صراع الحضارات" و منذ ذلك الوقت بدأت تعلوا الأصوات المنددة

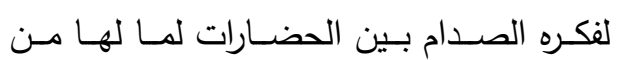
مخـاطر كبيـره علـى النظــام العـالمي القـادم محاولة تبنى نظره مغايره لهذه النظرة المعادية للسلام والأمن الدولي والعالمي، من هنا بدأت

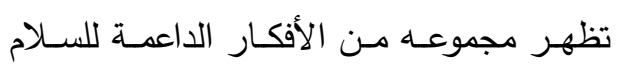

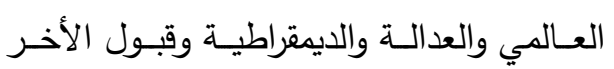

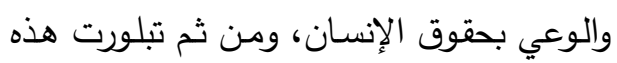
الأفكار والقيم جميعها لتتجمع في مفهوم واحد بد فيد

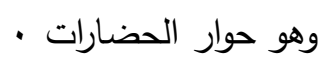

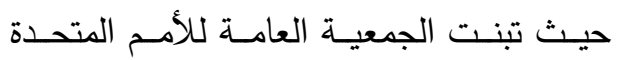

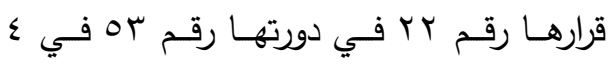
نوفمبر 991 بإعلان عام 1. . ب عاما للحوار بين الحضـارات اعتبرت القوى المحبـة للسـلام

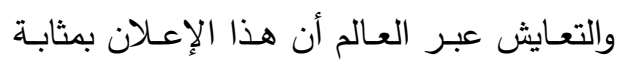

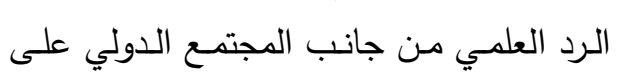

إلى أصل واحد على اختلاف أشكالهم وألوانهخ وألسنتهم ولكن أراد أن يجعلهمـا شعوبا وقبائل إستل

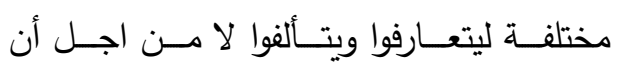

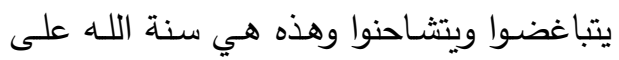

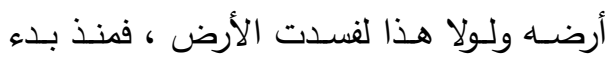
الخليقـة والإنسـان يتفاعـل ويتحـاور مـع أخيـه الإنسان ويتفاعل ويتأثر به فأدى ذلك كله إلى

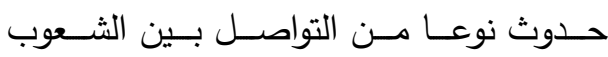

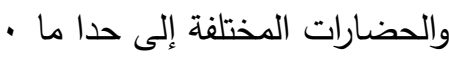

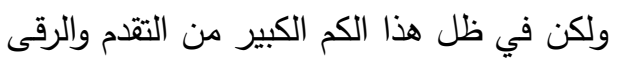
التكنولوجي والطفرة الهائلـة التي أحدثتها ثوره

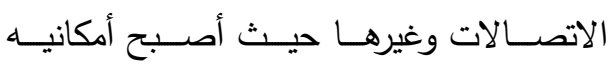
التواصل والتفاعل أيسر من ذي قبل فقد أصبح العالم اليوم قرية كونيه كبيره يتواصل فيها كلا مع الأخر في أي مكان وزمان · لمونه نشأه مفهوم حوار الحضار فات :

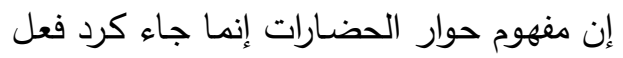

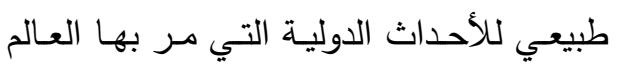

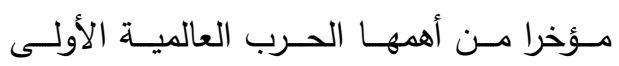

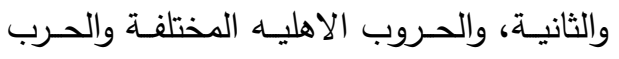
الباردة وانهيار ثم سقوط الاتحاد السوفيتي، ثم سقوط نظام الثنائية القطبية المان وهذا مـا عبر عنـه المفكر الامريكى الجنسية

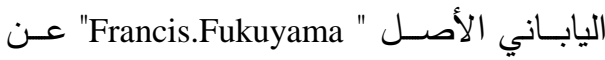
نهايــة تـاريخ الانسـانيه بانتصــار النمــوذج اللييرالـي الرأسـمالي الغربـي باعتبـاره انتصـارا نهائيا وترسيخا لسيادة هذا النموذج على العالم لئرسي 
الحافظـــة لتميـزه عـن الآخـرين عبـر الزمــان

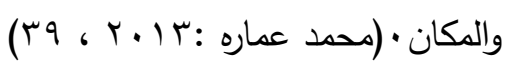
حيث يقول (محمد خاتمي )" أنه عندما يكون

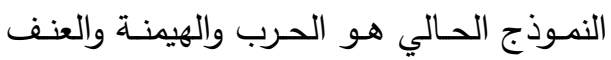
يحتاج العالم أن يسمع صوت السـلام والحوار" ,2012,pp3-14) (Mohammad Khatam لذلك لابد من تحليل هذا المفهوم الجديد على الساحة الدولية لمعرفه مضمونه وما يسعى إليه وذلك من خلال معرفة معنى هذا المفهوم سواء

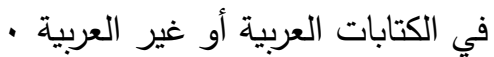
تعريف مفهوم حوار الحضار ات: لقــــــددت مفـاهيم الحـوار بـين الحضــارات وتعـددت الكتابـات التي تتاولت هـذا المفهوم بـالتعريف واختلف حولـه العديد مـن البـاحثين محاولهً منهم جميعا الوقوف على مغزى هذا

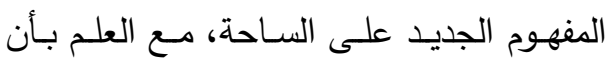

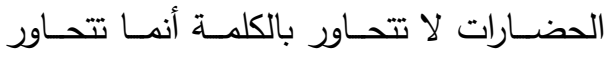

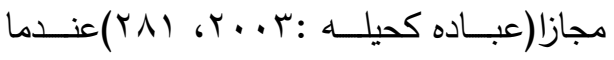
نتحدث عن حوار بـين ، كمـا يعرفـه (عـلاء

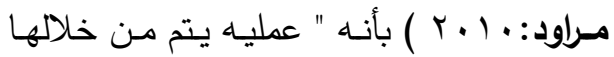
تبادل علاقات التأثير والتأثر بين الحضـارات المختلفة في جميع المجالات ،وتتم هذه العملية

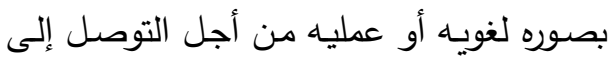

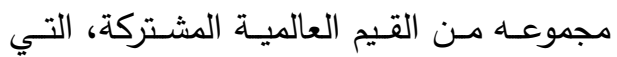

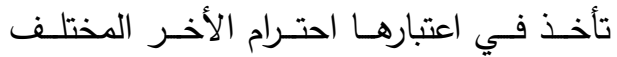

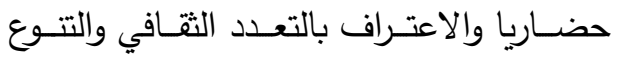

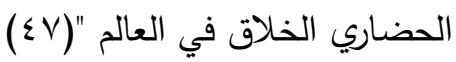

كل دعـاه الصـراع أو الصـدام بين الحضـارات والادعـاء بتفوق حضـارة على أخرى أو القول بـاه بنهاية التاريخ وانتصار حضـارة على الأخريات

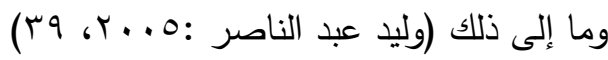
ونتج عن هذا الإعلان ظهور موضوعات كثيرة

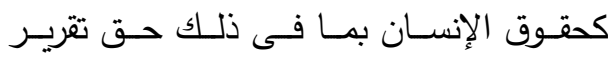

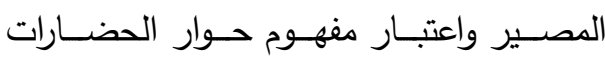
نموذجـا لتعزيـز العلاقـات الدوليـة بـين الـدول وإنهاء التهديدات الدوليه.

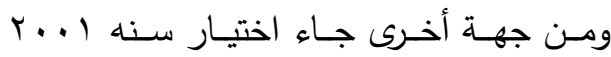
تحديدا بقصد أن يستقبل العالم الألفية الثالثة

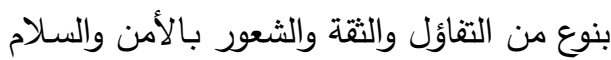
والاندفاع نحو تمديد وتطوير العلاقات الدولية

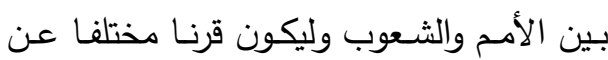
القرن العشرين الذي عد قرن الحروب الكبرى

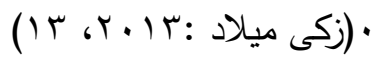

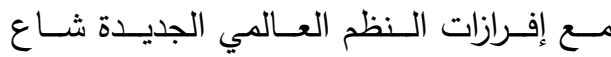
استخدام الحوار على كافه الأصعدة ، و بذلك الك الك قوى التواصل بين بني البشر ، حيث اتسعت

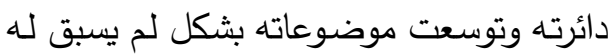
• مثيل لذا جاءت الدعوة التي تردد أن عالمنا يجب أن يكون " منتدى حضـارات " تتفاعل جميعا من موقف وموقع الرائد المستقل الذي يصافح الدنيا

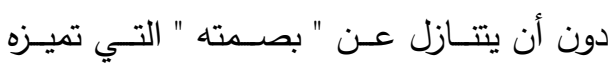
وهويته التي تحتل الجوهر والروح الحضـارية 
ترجع أهميه حوار الحضـارات فى أنـه الوسيلة الوحيدة لتأسيس نظام عالمي جديد يقوم على التى

التعارف والتواصل والتفاعل بين الحضارات . وقد أصبح الحوار اليوم ضرورة من كل وقت مضى لإنقاذ الحضارة المعاصرة من الوقوع في

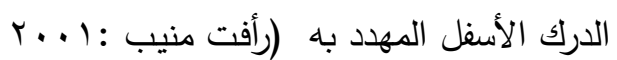

(1) ،

إن إحياء خطـاب الاعتدال والحوار يمكن إن يعزز ليس فقط الوحده الاقليميـه أو المحليه

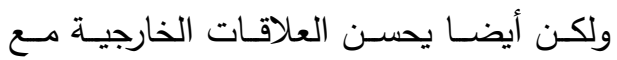
الدول الأخرى ،فمن خلال الحوار يمكن التأكيد على أن الظلم والطغيـان الذني أصـبح مـلازم للعلاقـات الدوليـة يمكـن احتوائـهـ مــع تعزيـز

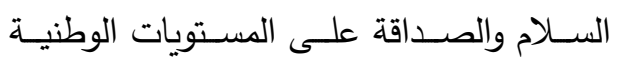
Gholanali

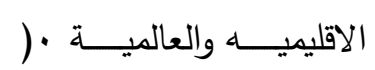

(khoshroo,2013

وهنا يمكن التأكيد أنه من خلال الحوار نشر

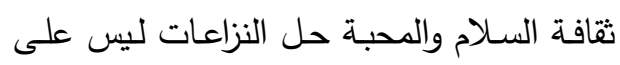
مستوى الفرد ومجتمعه فقط، وإنما يمتد ليشمل الإطـار الخارجي للعلاقات الدولية لمـا يشوبها

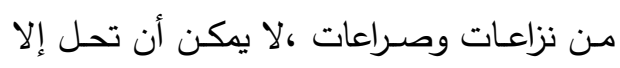

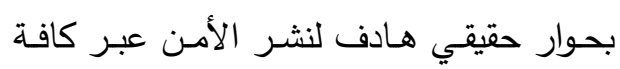
- المستويات ولقد ساهم العديد من الباحثين فى دعم مفهوم

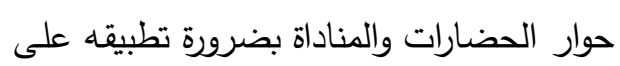
كافـه المستويات لمـا لـه مـن أهميـه فـى بنـاء

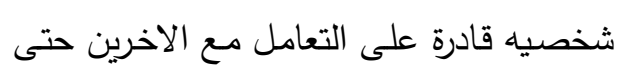

وقامت دراسـة (Altwaijri,2001) على تعريف

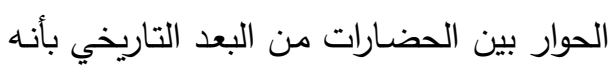

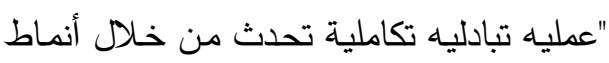

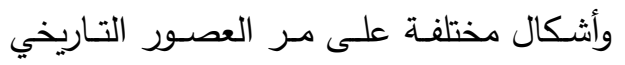
أجمع الباحثون على أن الحوار الحضـاري "هو

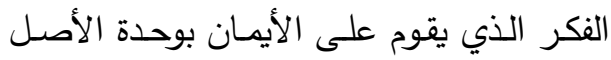
البشـرى والسـعي إلى تأسـيس شـراكه إنسـانيه صحيحة وعادله ، تبتغي تأسيس وحده كونيـه

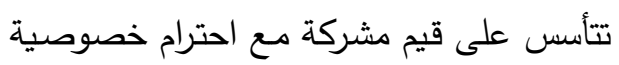

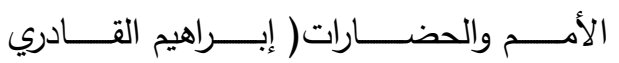

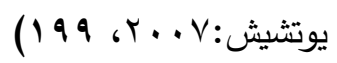
يتضح من كل هذه التعريفات أن حقيقة الحوار

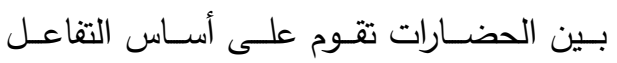
الايجـابي بين الثعوب فـى مسيرتهم المختلفة

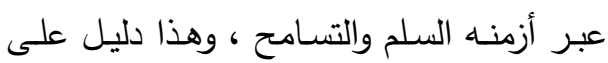

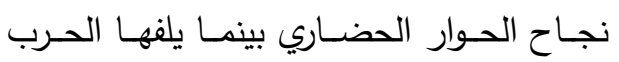

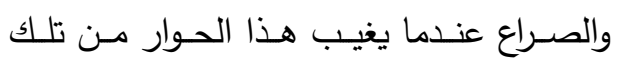
- الأزمنة ويعرفهـ البحث الحسالي بأنـه"هو عمليه التأثير

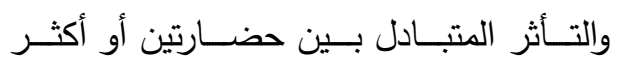
أساسـهما الاخـتلاف ولكـن مـع وجـود قواســ مشتركه بينهمـا ،وذلك للخروج بمجموعـه مـن

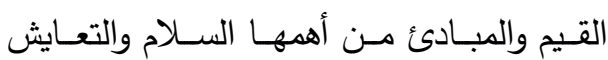
السلمي ،ومراعاة حقوق الإنسان واحترام الأخر

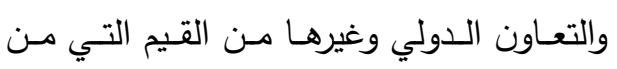
شانها أن تعلى قيمه الفرد داخل مجتمعهد.

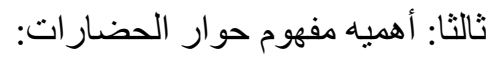


والمجتمعات ، لوضع أسس الحوار على أساس

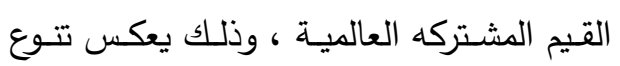

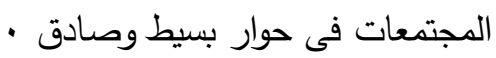

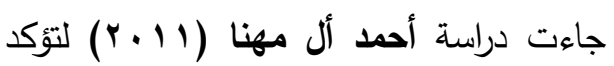
على أنه بقدر ما كانت الحروب سبب للدمار فقد أدى إلى انتقال المعرفة وغيرها من مكونات

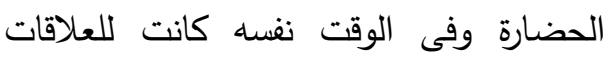
السليمة والحوار دورا كبيرا في تحقيق التواصل - الحضاري وبناء الثقافات إن وجود أرضـيه مشتركه مـن القيم العالميـة

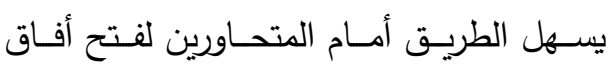

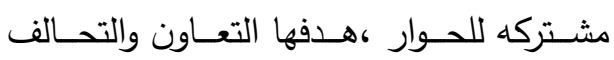

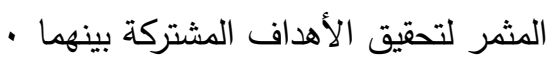

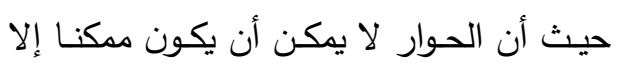
إذا كان أسساس قيامه العدل والمساواة والاحترام المتبادل بحيث تكون قاعدة أساسيه يسير عليها

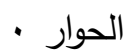

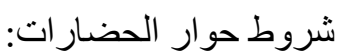

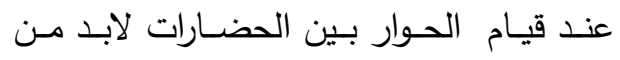
مراعـاة مجموعـهـ مـن الشـروط الواجب توافرهـا حتى يحقق أهدافه المنشودة، ولكن بشرط توافر هذه الثـروط حتى يسير الحسوار في مسـاره

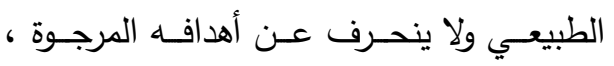
لتحقيـق أعلـي قـدر هـــه الأهـداف والآمـال

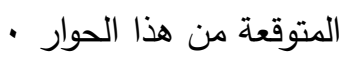
حيث يتطلب الحوار الاستماع إلى الآخرين

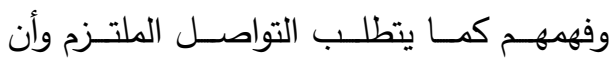
الحوار يفتح الأبواب ويبنى الجسور ، كما أنـ ولنه
ولــو اختلفـوا فـى وجهــات النظـر مـن هــــه

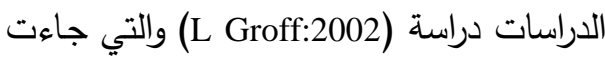
لتؤكد على أهميه الحوار فى خلق ثقافة واعية لدى الإنسان لتطبيق الحوار فى كافه المجالات المختلفة حتى نصل إلى السلام العادل بين كل

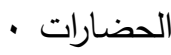
أهداف مفهوم حوار الحضار ات: يهاف الحوار إلى جمله أمور من أهمها : 1- تعزيز العدالة والمساواة والتسامح.

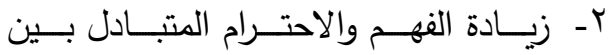
الحضارات

r- تحديـد أرضـية مشـتركه بـين الحضــارات لمواجهـه التحديات المشتركة التي تواجـه القيم الانسانية وحقوق الإنسان ـ - انجازات المجتمعات البشرية وحماية حقوق البقات الإنسان وإثراء الفهم المشترك لها. 0ـ تتميه أفضل للمعايير الاخلاقية المشتركة والقيم الانسانية العالمية •

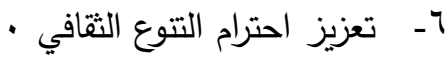
V- كمـا يهدف وجود حوار بين الحضـارات بشكل فعال ومستمر أمر ضروري لتحقيق أهداف كثيرة من بينها: (وليد عبد الناصر (0, T. . O : و يشير Hans d Orville,2012 أن الحوار بين الحضـارات عمليـه تهـدف إلىى تحقيق العدالـة والمساواة والتسامح بين الناس والعلاقات ،والذي يهدف لسد الفجوة فى المعرفة فى جميع أنحاء

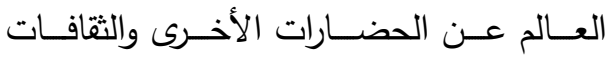


يستمد حيويته من التفكير المتأمل في مواقفنا الحوار أكثر فاعليه وأيسر في تحقيق هدفه وكذلك مواقف الآخرين، فالحوار يثمل العقل المنشود على أساس موضوعي سليم ل

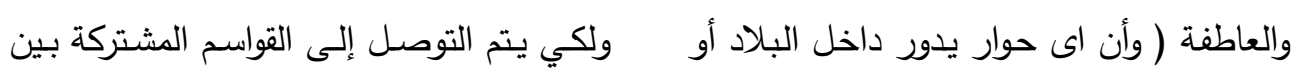

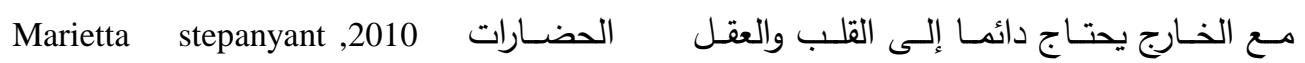
وحريـة الرأي وتعدد الأراء · (حامد بن احمد توضح أنه من خلال فهم الأسباب التي جلبت

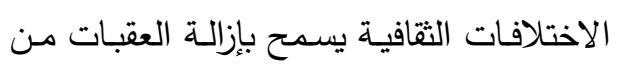

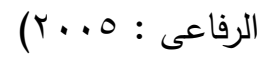

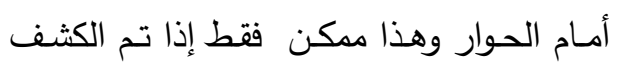
عن القواسم المشتركة (7304-7299 ) يقول Samuel. Huntington في معرض حديثه عـن صـراع الحضــارات :" لـن تكـون هنـاك فيك

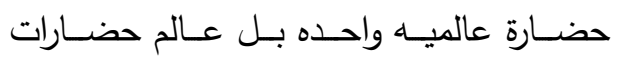

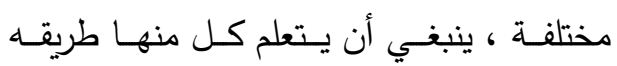
التعايش مع غيرها ووجوب بذل جهد لتحديد ما

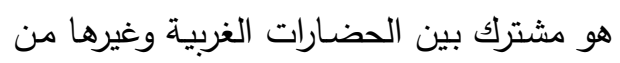

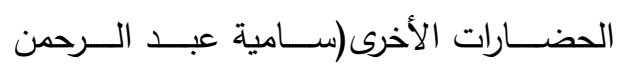

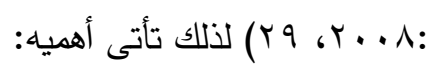

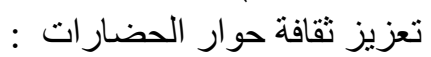
لتعزيز ثقافة حوار الحضـارات لابـد من إتباع

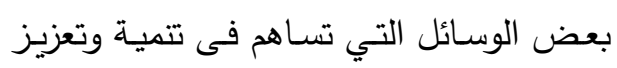

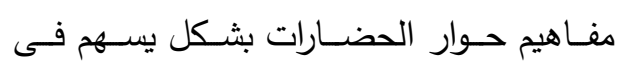
تحقيق التفاهم المتبادل لذلك لابد من Victor

(segesvary,2004, 59)

ا - إدخـال بـرامج تهـدف إلى تعزيـز التفـاهم والتسامح مع مختلف الثقافات والحضـارات

فى المناهج التعليمية المختلفه .

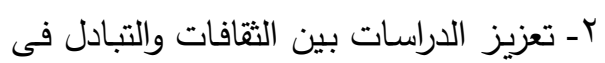

$$
\text { مؤسسات التعليم العالي ل }
$$

يمكن تحقيق الحوار إذا كان شرط قيامه هو خلق جو من التفاهم والحوار الديمقراطي القائم

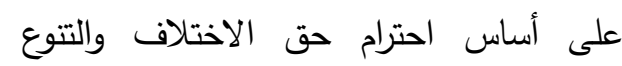
· الحضاري فحوار الحضارات لن يكون ممكنا إلا إذا كان

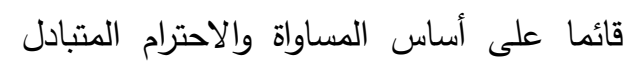
واحترام القيم الثقافيه التي تثرى روحيا الأجيال

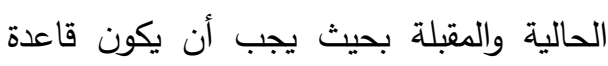
أخلاقيه سواء على أي مستوى :United) national , 2004,38-39

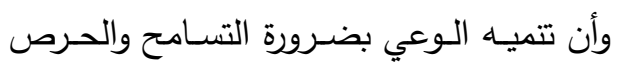

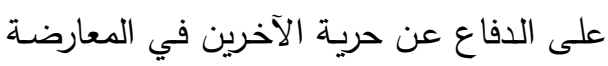
والنقد على المستوى الوطني واستيعاب المفاهيم الحضــارية مـن منظـور إنسـاني شـامل على لـى

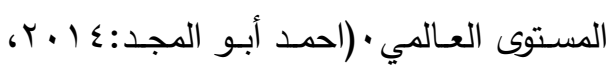
القواسم المشتركة في حوار الحضار ات:

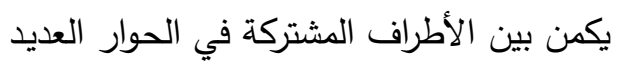

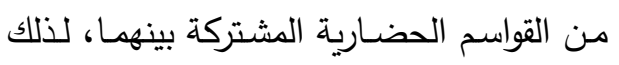
عندما يحدث حوار بين حضـارتين مختلفتين تقومان على أساس ثابت من القواعد المشتركة

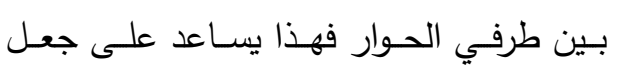


لذا ينبغى أن تثمل على غرس الوعي بالقيم الحضارية المشتركة ومن أهمها بطبيعة الحال احترام الحضارات الأخرى واحترام ثقافاتهم وهذا

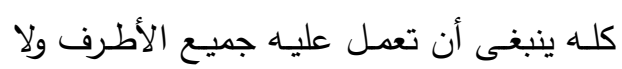
سيما المؤسسات التعليميه. لقد غدا التعليم مـن أجلـ نشـر ثقافـه السـلام

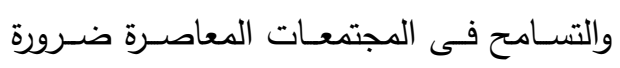

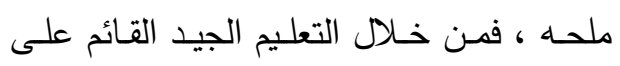

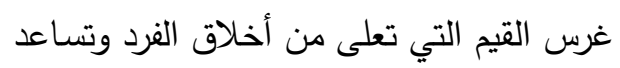
علـى تتميـه الحــوار والتفــاهم بــين الأفـراد

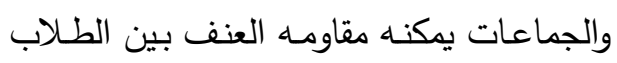

لذلك فحن فى حاجها ماسـه إلى تطوير النظام

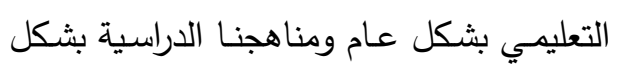
خاص، وذلك لكي نحقق ما نرجوه من مفاهيم

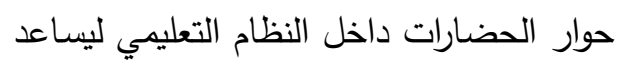

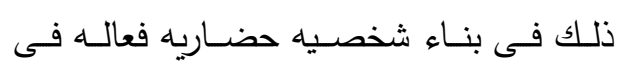

مجتمعاتتا وبذلك ترتقي المجتمعات بأبنائها يقول"JonWiles,2009" أنـه مـن خـلال عمليـة التطوير يبلخ المنهج ذروته فى تحقيق خبرات

$$
\text { التعلم الناحجه •(2) }
$$

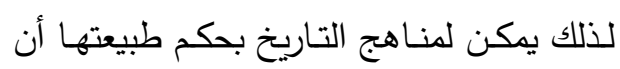

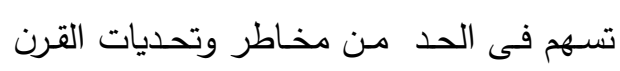

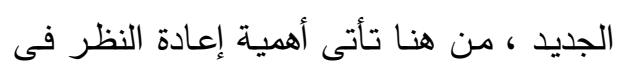

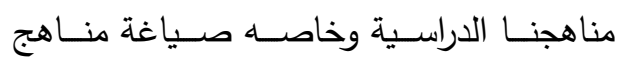
التاريخ عالميا لتواكب هذه التغيرات العالمية. r- الأستفادة من الثورة التكنولوجية من خلال

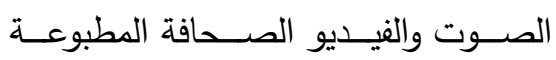

وتكنولوجيا الوسـائط المتعددة لنشـر ثقافة

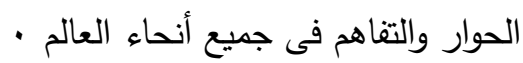

ع - تثجيع السياسة التاريخية والثقافية كوسيلة

$$
\text { لـ لحوار والتفاهم بين الحضارات . }
$$

๑ـ إجراء الدراسات حول سبل ووسائل تعزيز

التبادل والتقاعل بين مختلف الثقافات التراء

7- تشجيع منظمات العمل المدني والمنظمات

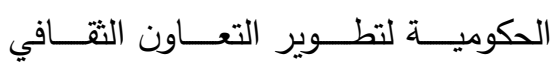

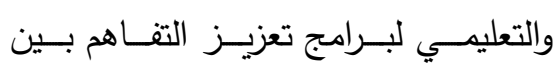

$$
\text { · الحضارات }
$$

تعتبر هذه مـن الوسـائل التي يمكن إتباعهـا

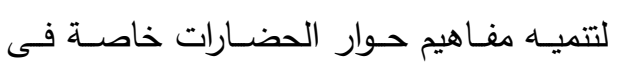

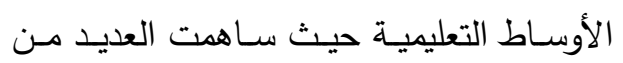
المنظمـات بالمبـادرة لـدعم حـوار الحضــارات سواء من خـلال برامج أو ندوات أو مؤتمرات

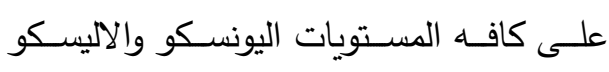

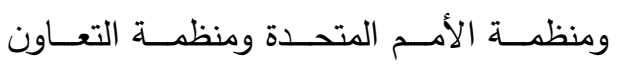
الاسلامى وغيرها إلا إن هذه المبادرات لابد لها

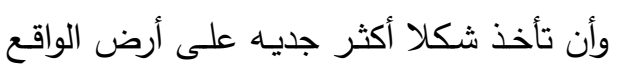
ومن هنا يأتى : دور مناهج التاريخ فى تفعيل حوار الحضارات وبنـاءً على ماسبق فـإن التوصـل إلـى تفــاهم

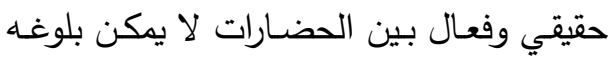

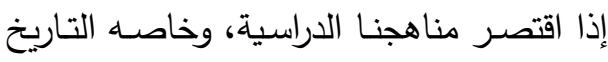

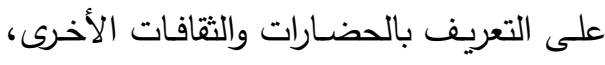




$$
\begin{aligned}
& \text { 1- السعي لإيجاد بيئة دولية سليمة ومستقره } \\
& \text { تقــوم علــى أســاس الاحتـرام المتبــادل }
\end{aligned}
$$

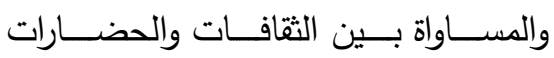

$$
\begin{aligned}
& \text { المختلفة وعدم إزدراء الاخر - الإن }
\end{aligned}
$$

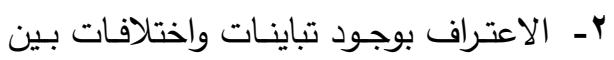

$$
\begin{aligned}
& \text { الحضارات والثقافات . } \\
& \text { r- ـــوار الحضـارات أو تحــالف الحضــارات }
\end{aligned}
$$

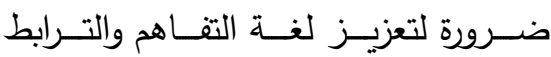

$$
\begin{aligned}
& \text { ويحصل التقارب بين الثقافات . }
\end{aligned}
$$$$
\text { ع- تتميـه الثخصـية الانسـانية التـي تـؤمن }
$$$$
\text { بمبــادئ التســامح والحربـــة والمســـاواة }
$$

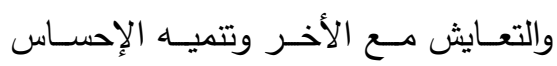$$
\text { بالمسئولية الاجتماعية لدى الطلاب . }
$$

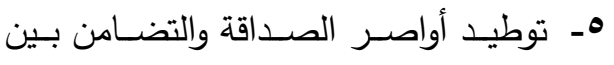$$
\text { الثـعوب وتعزيـز احتـرام الأخـر وصـيانة }
$$$$
\text { • التعدد والتتوع الثقافي وتعزيز }
$$

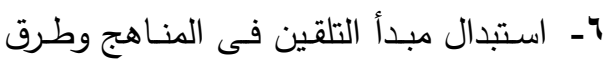$$
\text { التدريس السائدة فى مدارسنا بمبدأ الحوار }
$$$$
\text { وترسيخه فى ثقافة الطلاب ل }
$$

V- إيجـاد ثقافـة نقديـة لدى الطـلاب بـالتمييز بين الحق والباطل، فـى الهجـال الفكري

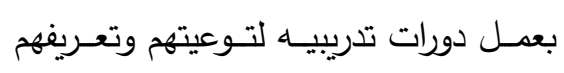

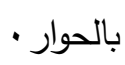$$
\text { ^- - حـث الطــلاب علـى الاهتمــام بالبحــث }
$$

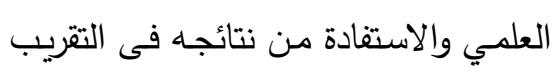

$$
\text { ·ين الحضارات }
$$

و من خـلال تثمين مناهج التاريخ بالعديد من قيم ومفاهيم الحوار كالتعايش السلمي والحريـه والعدالة والمساواة والوعي بقبول الأخر وصولا للسلام العالمي وتجسيد ذلك فى نفوس الناشئة تسهم ماده التاريخ بدور بارز فى تشكيل فكر

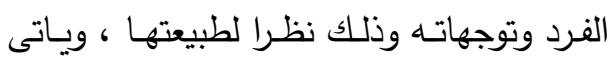

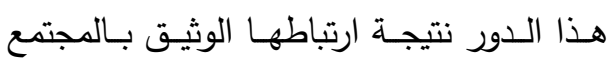
والتغيرات الحادثة فيـه في الماضـي والحاضـر والمستقبل (على احمد الجمل :0. . ب.، ( ) كما تعد مناهج التاريخ من أكثر المناهج التي لهي يمكن أن تلعب دور القيادة فـى دعم مفاهيم حوار الحضارات، وخاصه فى المرحلة الثانويـة ،وذلك لمناسبتها مـع مفاهيم حوار الحضـارات

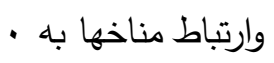

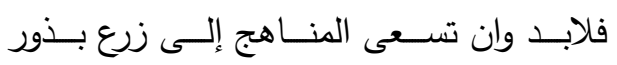

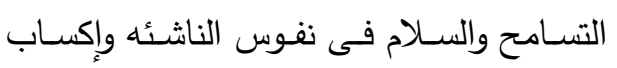

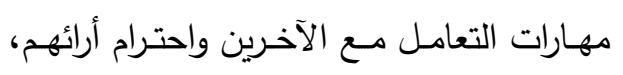

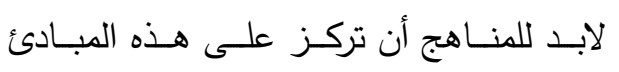

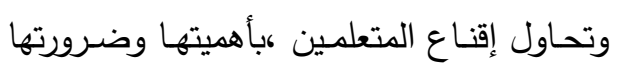

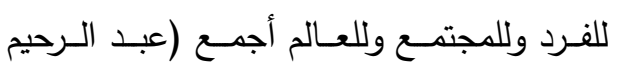

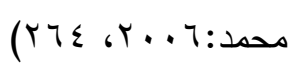
لمنـاهج التاريخ دور كبير فى تدعيم مفاهيم حوار الحضارات وذلك بسبب أن مناهج التاريخ بوجه خاص دور كبير فى ترسيخ ثقافه الحوار

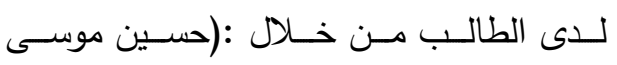
$(1 \cdot 1-9964 \cdot 1)$ : 
الإنسـان والتسـامح والمواطنة والديمقراطية، لذا يجب مراجعه هذه المبادئ عند مراجعه المناهج

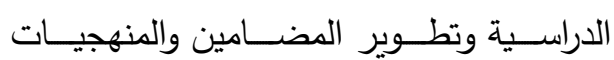

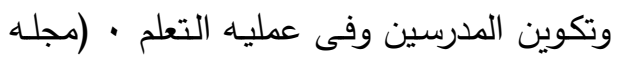

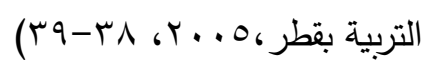

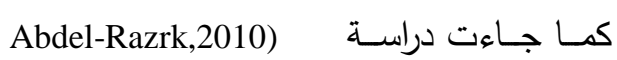
(Selah إطار التعليم ووضعهه على نحو فعال والتعبير عن حـوار الحضـارات فـى جميع المستويات

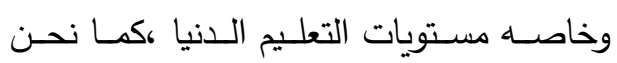
بحاجـه إلى تثقيف وسـائل الإعـلام وصـياغة

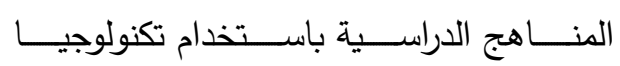
المعلومـات والاتصـالات الحديثه لتحقيق رؤيـا · أكثر للواقع

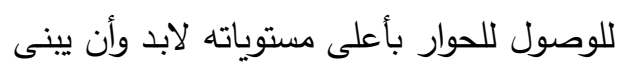

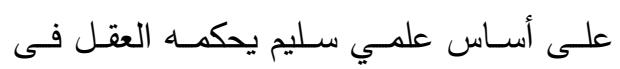

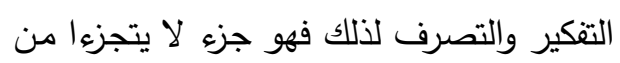
• التفكير الانسانى ومـن هنـا أصـبح الحـوار أحـــ أشـكال الـتعلم

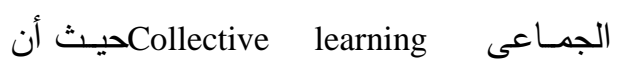
الاختلافــات الثقافيــة فــى عمليـــه التفكيــر الانسـانى، التي تحكم بـدورها الأفكار والقيم

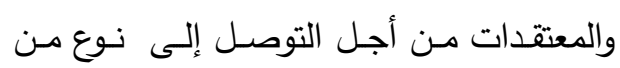

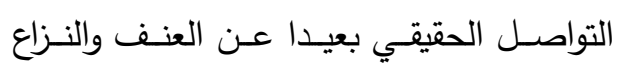

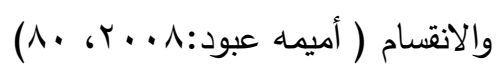

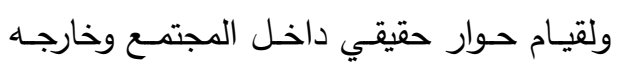
وعلى كافه الأصعدة والمستويات بالثكل الذي داتي ولئي
وان يـؤمن هـؤلاء المتعلمـين بـأن تعـدد الآراء

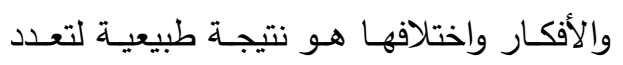

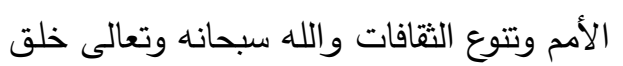
الناس شعوبا وقبائل ليتعارفوا . عندما نهيـأ للطـلاب الجـو المناسـب والبيئة والإمكانـات الداعمـة لحـوار الحضــارات وقتهـا سيتعاملون أكثر وسيستجييون لكل ما يقدم لهم وخاصه إذا ربطنا هذا الموضوع بمجال حياتهم ليوميه - لئ ومن أهم تحديات القرن الحادي والعشرين هي الدعوة إلى التعايش السلمي فى القرن الحادي

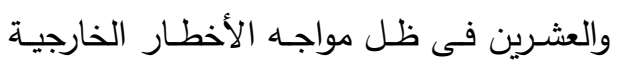

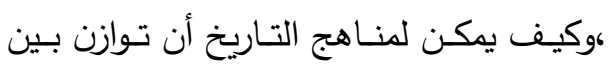

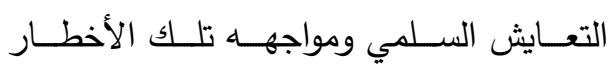

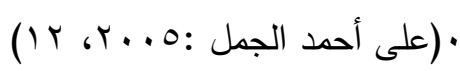
مناهج التاريخ لها دور كبير فى دعم مفاهيم

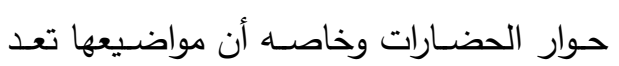
تربـه خصـبه يمكـن مـن خلالهـا زرع مفـاهيم حوار الحضـارات للطلاب، وتتبت بعدها ثمار

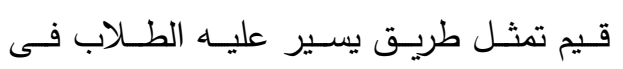
- المستقبل كما أوصى المؤتمر الذي عقد مؤخرا فى الرباط حول " تعزيز الحوار بين الثقافات وإلحضارات

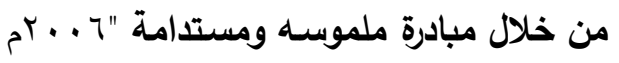
شاركت فى تتظيمـه ست منظمات دوليه ،بانهـ

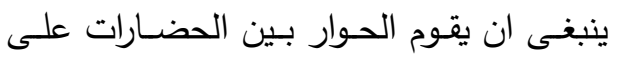
القيم الانسانية المشتركة ومبادئ السلام وحقوق لئو لئن 
التــي تــدعوا لبنــاء أوطانتـا، بأيـادي السـلام

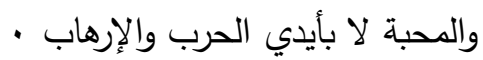

مفــاهيم حــوار الحضــارات الواجـب توافرهــا بمناهج التاريخ بالمرحله الثانوية : تعد مفاهيم حوار الحضـارات شكلا مبسطا لما بـا

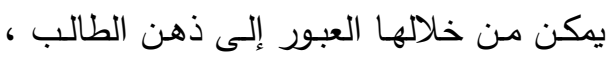

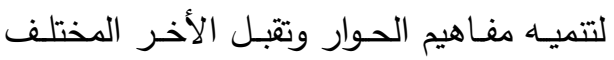
حضاريا ولتتميه ثقافة الأخر وقبوله ،ويمكن أن الن تتلخص هذه المفـاهيم فـى النقاط التاليـة كمـا

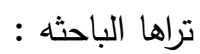
1 - علاقات التأثير والتأثر بين الحضارات : r- احترام الخصوصية الحضاريه. r- التقاء الثعوب فى ظل العلام القات الدوليه.

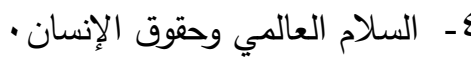
هـ ـ القيم العالمية المشتركه. T- التتاغم الحضاري فى سياق العولمه.

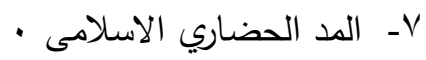
1- العزلة الحضارية • يحمـل كـل مفهـوم مـن المفـاهيم السـابقة العديد من القيم والمبادئ التي يحتويها حتى هئ لهئ يحقق أهدافه المنشودة ،فهي عباره عن نتائج تطبيق حوار الحضـارات على الساحة الدولية

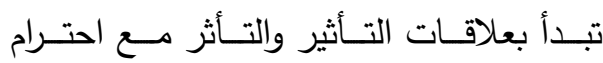

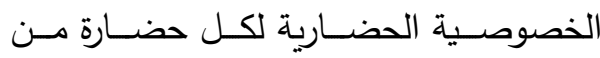
الحضارات المتحاورة ، مما يسهل الطريق لفتح علاقات دوليه قائمسه على التفاعل والتواصل
يسهم فى تحقيق غاياتـه وأهدافـه المنشـودة إذ

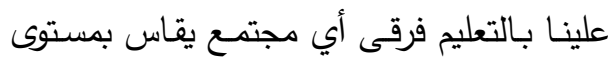

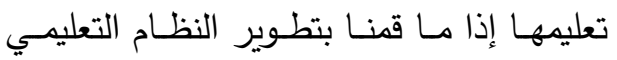

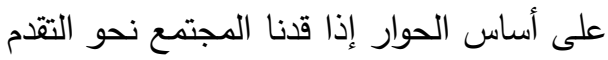

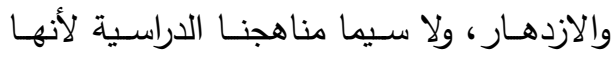

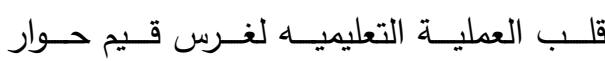
الحضـارات فى نفوس الطـلاب ،للمسـاعدة فـى لفي خلق جيل واعي باهميه الحوار فى حياته وحياة

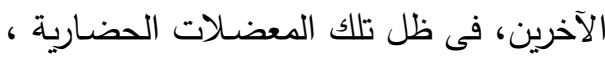

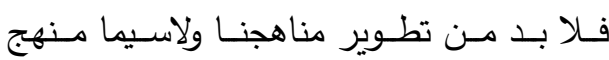

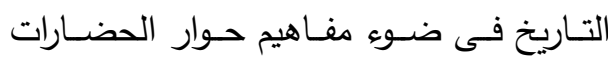

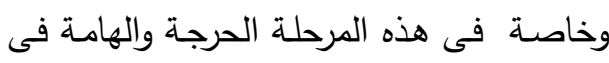

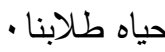
لـذلك فـإن مرحلـهـه الدراسـة الثانويـة فتره تربيـهـ وتعليم مواطن ، بأعتباره شخصا منتجا مسئولا لخان لشعوره بالانتماء إلى مجتمعـه يقوى للحد الذي باعباره

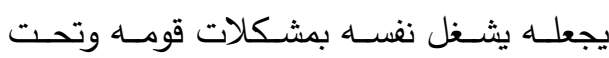

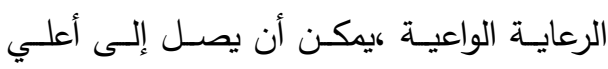

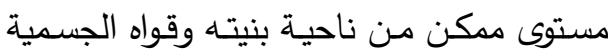

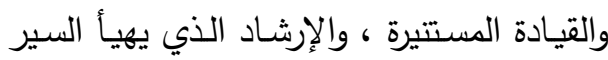
بنـــوه اجتماعيـا بثـكل يحقـق فيـهـ صــفات

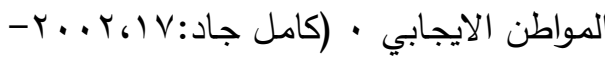
- (1)

هنــا تكمـن خطــورة وحساسـية هـذه المرحلــة الحرجة فى حياه طلابنا حيث يمكن من خلالها بنـاء الإنسـان ،وغـرس القيم الانسـانيه الفعالـة 
حول الحوار بين الحضارات بالمقررات الدراسية

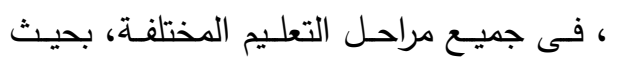

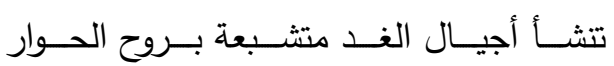

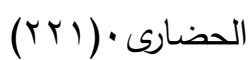
من هنا تأتى الحاجـة إلى إخراج كتبـا جديدا

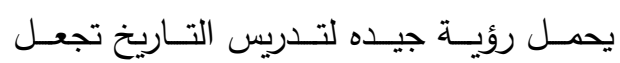
مخططـي المنــاهج ومعلمسي التـاريخ يعيدون النظـر فيمـا يقدم لأبنائنسا، مـن مفـاهيم السـلام

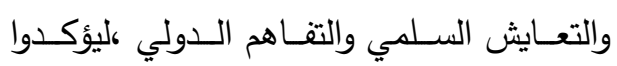

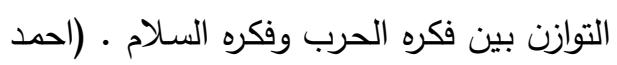

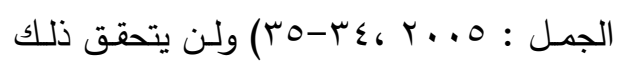
بثـكل جيــد بــدون مراعــاة مفــاهيم حـوار الحضـارات فى تطوير مناهج التاريخ بالمرحلة الثانويه . مشكله البحث : من خـلال الاطـلاع على الأدبيات والدراسـات

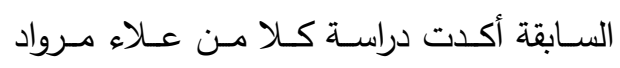

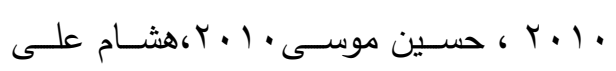

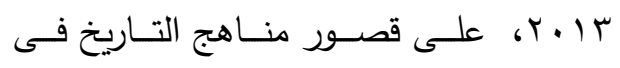

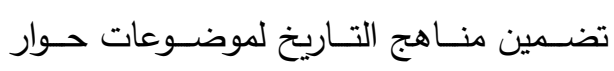

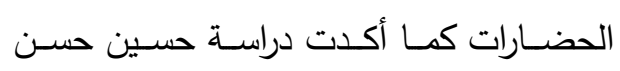

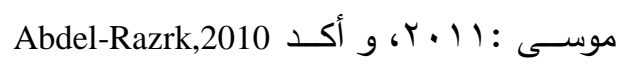
Selah التعليميه وضم موضوع حوار الحضارات إليها

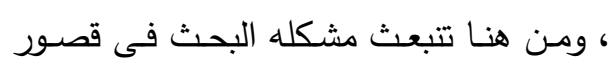

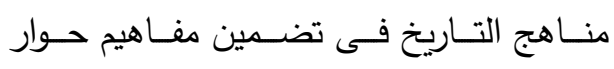
الحضارات ،وتتفرع من هذه المشكلة الأسئله

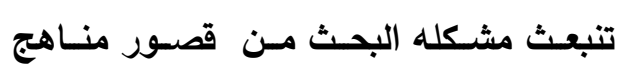

لحل مشـكلاتها المتثــابكة ، وصــلا لسـيادة

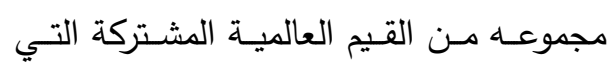

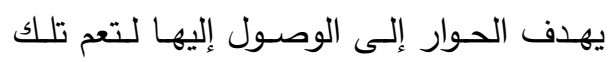

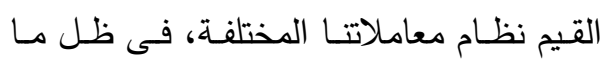

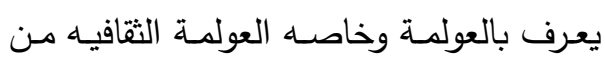

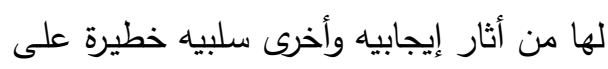

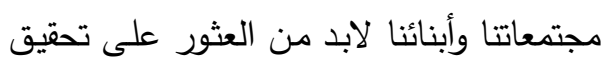
التتاغم الحضاري حتى لاتصل لمرحله العزلة الحضـارية والتي ستتنهي بكل حضـارة تتبعها إلى الانتهاء والانهيا - التهيك

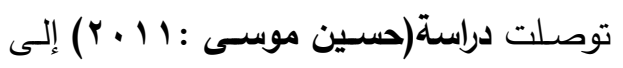

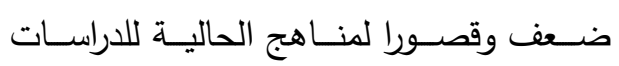
الاجتماعية والمناهج الأخرى ،فى غرس ثقافة حوار الحضارات لدي الطلاب وكيفيه المطالبة به وأهيته فى إيجاد ثقافة نقدية لدى الطلاب

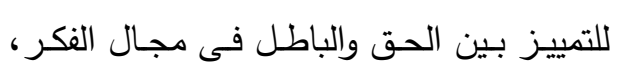

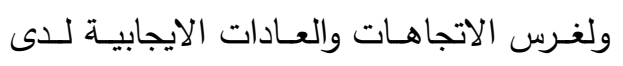

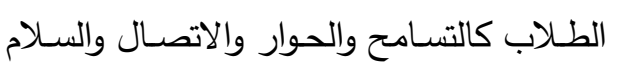
وقبول الأخر وعدم الصدام والصراع لما له من واله والهال

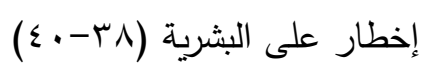

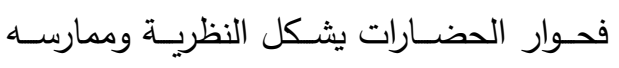
العلاقـات الدوليـة المعاصـرة لأفـاق عـالم أكثر لـثر سـلاما وعـدلا واعتبـار الحـوار نموذجـا بـديلا

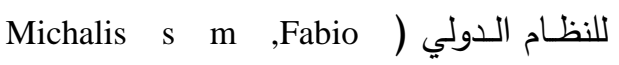
(petito,2009,11

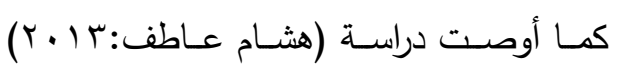
على ضـرورة إدراج مـاده تعليميـة متخصصــة 
الحضارات وذلك لتحديد نقاط القوه والضعف ،

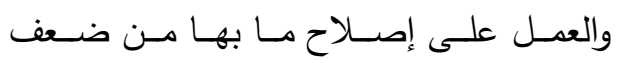

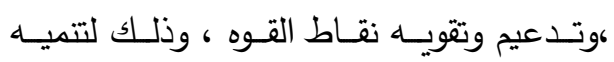

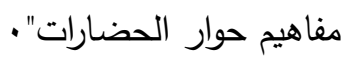
rialogue of - مفهوم حوار الحضـارات civilization يعرفه علاء عبد الله أحمد مراود: • 1 . ب بأنه

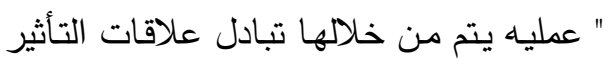

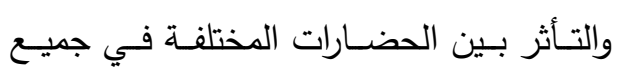

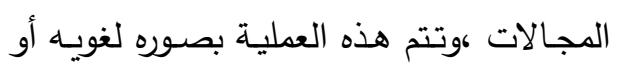
عمليه من أجل التوصل إلى مجموعه من القيم العالمية المشتركة التي تأخذ في اعتبارها احترام الأخر المختلف حضـاريا ،والاعتراف بالتعدد الثقافي والتتوع الحضاري الخلاق في العالم" • يقصد بحوار الحضـارات فى البحث الحالي :

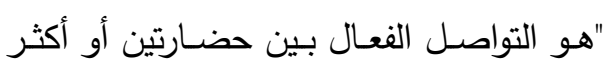

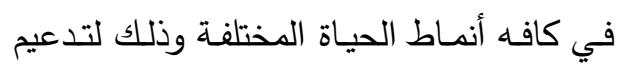

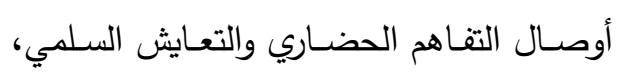

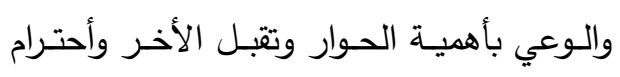
خصوصية الحضارات المختلفة ، وذلك لتتشئه مـواطن عـالمي قادر على التواصل والتفاعل الحضاري أهداف البحث :

$$
\text { يهاف البحث الحالي إلى : البحث : }
$$

1- الكثــف عـن وجـود قصـور فـى منــاهج التاريخ بالمرحلة الثانويـة لتضـمين مفاهيم

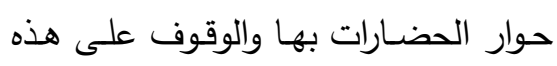

التاريخ بالمرحله الثانويـة فى تدعيم مفـاهيم حوار الحضارات بثكل جيد ، وتتفرع من هذه باله المشكلة الأسئله الفرعية الاتيه: ا - ما مفاهيم حوار الحضارات الواجب توافرها

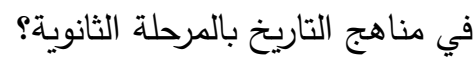

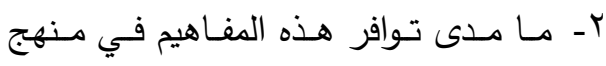
التاريخ بالصف الأول الثانوي العام ؟ هلاهب

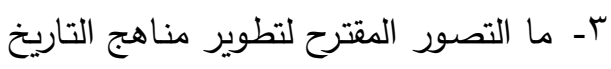

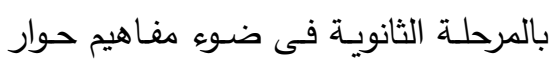

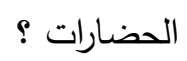

ـ - مـدى فعاليـة وحـده تعليميـة مطـوره مـن التصور المقترح فى تتميه وعى التلاميذ فعلئ بمفاهيم حوار الحضارات؟ مصطلحات البحث:

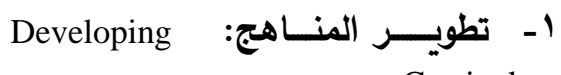
Curriculum

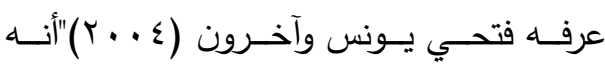
مجموعـه الإجـراءات التي تـتم بقصــ أحـداث تغيير كيفي فى أحد مكونات المنهج أو بعضها

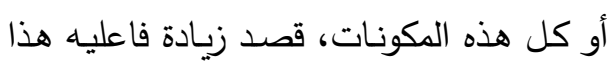

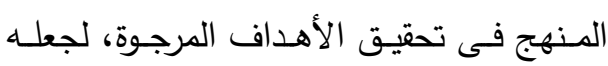
يتماشسى مـع بعض التغيرات والمستجدات فى لئ مجتمـع مـا أو مـع بعض لعض المستجدات العالميـة ( $($ q ) .

\section{يقصد بتطوير المنهج في البحث الحالي : "}

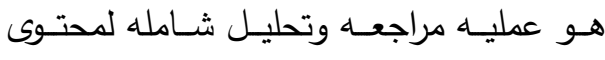
المناهج الدراسية ، للتعرف على مدى ما حقتته

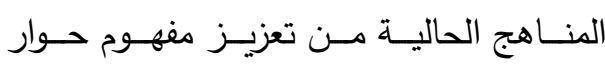


- قائمه بمفاهيم حوار الحضارات - تحليل منـاهج التاريخ بالمرحلـة الثانويـة لعام

$$
\text { الدراسي } 10
$$

- تجريب وحده تعليمية مقترحسه من وحدات

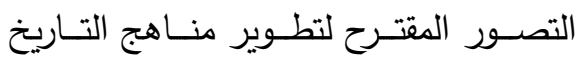

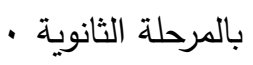

$$
\text { أدوات البحث : البر }
$$

- قائمــة بالمفــاهيم المتضـــــة لمفهـوم حـوار

$$
\text { الحضارات (من إعداد الباحثة) }
$$

- تصــور مقتـرح لتطــوير منــاهج التــاريخ بالمرحلـة الثانويـة فـى ضــوء مفـاهيم حـوار

$$
\text { الحضارات }
$$

- وحده تعليمية من التصور المقترح لتطبيقها على طلاب الصف الثانى الثانوي فى ضوء

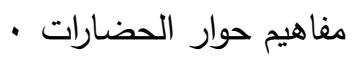

-اختبار تحصيلى لقيـاس مدى وعى طـلاب المرحلـة الثانويـة بمفـاهيم حوار الحضـارات،

$$
\begin{aligned}
& \text { يطبق قبلى وبعدى } \\
& \text { فرض البحث : }
\end{aligned}
$$

الفرض التجريبي / وهو فعالية وحده مطوره من التصسور المقترح لمنـاهج التاريخ بالمرحلة

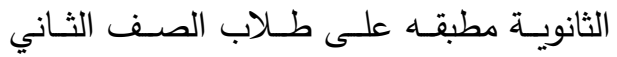
· الثانوي الفـرض الاحصــــ / توجد فروق ذات دلالـهـ

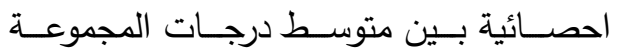
الظابطة والتجريبية قبل تدريس الوحدة المطورة

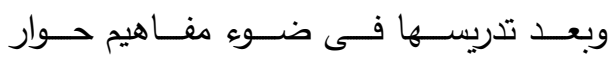

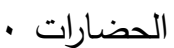

المفـاهيم الواجب توافرهـا بمنـاهج التـاريخ

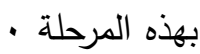
r- إعادة النظر في مناهج التاريخ بالمرحلة الثانويـة والعمـل على تطويرهـا في ضـوه مفهوم حوار الحضارات . r- تضمين مفاهيم حوار الحضـارات بمناهج التاريخ بالمرحله الثانوية لإعداد جيلا قادر لهين

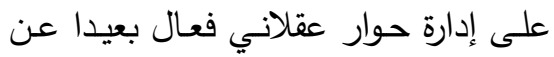

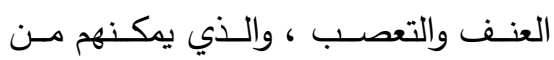
التفاعل الذكي المنتج مع معطيات العصر ولتعر ولتصن والمستقبل ، وتحديات العولمـة في إطـار

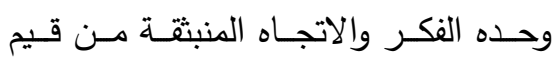
حضارتتا العربية الاسلاميه" • أهميه البحث : ترجع أهميه البحث الحالي فيما يلي :

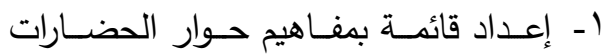
يمكن الاسـتفادة منهـا فـى بنــاء منــاهج التاريخ بالمراحل التعليمية المختلفة r- توجيه نظر القائمين على تطوير المناهج

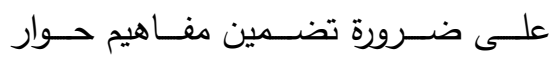
الحضارات بالمناهج الدراسية ل r- تقــديم تصــور مقترحسا لتطــوير لمنــاهج التاريخ بالمرحلة الثانويـة فى ضوء مفاهيم - حورا الحضارات ع - تزويد معلمي التاريخ بوحدة معاد صياغتها وفق مفاهيم حوار الحضارات. حدود الدر اسة : يقتصر البحث الحالي على الحدود التالية: 
- مطابقتها مـع قائمسه المفاهيم المتضـنة فى م

$$
\text { - حوار الحضارات }
$$

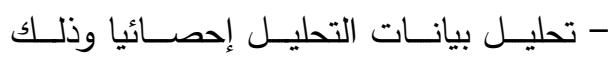
للوقـوف علـى مـدى تـوافر مفــاهيم حـوار

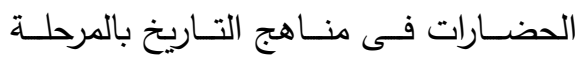

$$
\text { • الثانوية }
$$

ثالثـا : إعـداد تصـور مقتـرح لتطـوير منــاهج التاريخ بالمرحلة الثانوية فى ضوء مفاهيم حوار

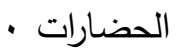
رابعـا :اختيـار و وحـده تعليميـة مـن التصــور المقتـرح ومعالجتهـا فـى ضــوه مفــاهيم حـوار الحضارات وتطبيقها على طلاب الصف الثاني الثانوي ، وتصميمها تفصيليا مع تحديد عنوانها

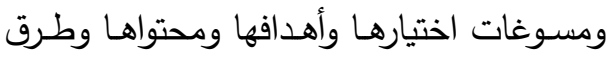

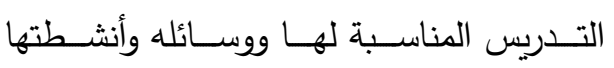
التعليمية وأساليب تقويمها سادسـا : إعداد دليل لمعلمي المرحلة الثانويـة

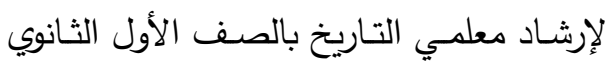
عن كيفيه شرح الوحدة المطورة في ضوء حوار

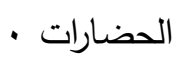

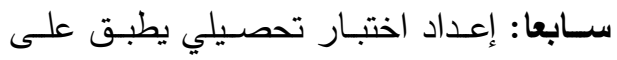
طـلاب الصـف الثاني الثانوي ، لقياس مدىى لئس

وعى الطلاب بمفاهيم حوار الحضارات .

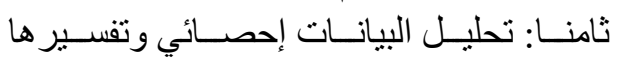

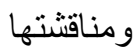
تاسعا: تقديم المقترحات و التوصيات فى ضو و النتائج

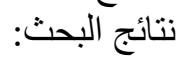

منهج البحث :اعتمد البحث على: المنهج الوصفي التحليلي : فى تجميع المادة العلمية للإطار النظري لنطوير مناهج التاريخ

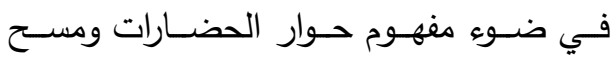
الدراسات السابقة في مجال موضوع البحث هذا الاضـــافة - عمــل قائمـــه بمفــاهيم حــوار الحضــارات وأيضـا فـى تحليل منــاهج التـاريخ

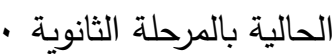
- المنهج شبه التجريبي : يتم استخدامه عند

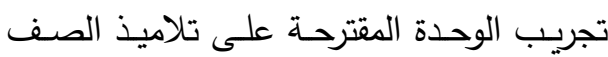
الثاني الثانوي لقياس مدى فاعليتها في تحقيق تلاديق

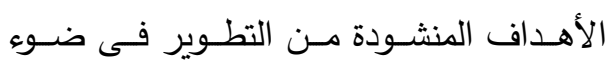
مفاهيم حوار الحضارات. إجراءات البحث : مارئ قامت الباحثة بالخطوات التالية : أو لا :إعداد قائمه باهم مفاهيم حوار الخار الحضار ات - من خـلال مراجعـه البحوث والدراسـات

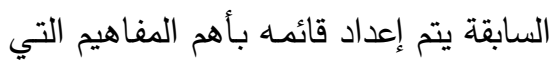
يتضمنها مفهوم حوار الحضارات وعرضها فى صورتها الأولية على الدحكين لإبداء أرائهم ووضعها فى صورتها النهائيه. ثانيا : تحليل محتوى منـاهج التاريخ الحالية

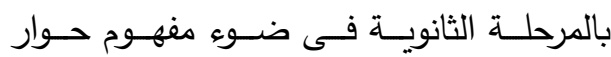

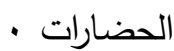
- إعداد قائمه بأهم المفاهيم التي تثتمل عليها

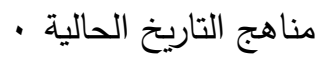

تتحدد نتائج الدراسة فى النقاط التالية : 
r- تطوير منـاهج التاريخ بصف مستمرة من

خلال متابعة كل ما هو جديد على الساحة

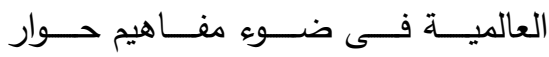

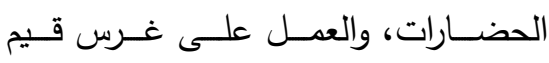

ومفاهيم الحوار فى نفوس طلاب المرحلة

الثانويـة ، لإعداد مـواطن قـادر على أدره

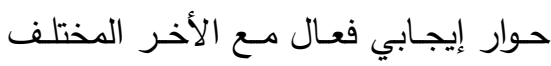

$$
\text { • حضاريا }
$$

ع - إضــافة مفــاهيم حـوار الحضـــارات فـى هـ

المنـاهج الدراسية وفى المراحل التعليميـه

المختلفة والتدرج فى إضـافتها بما يتتاسب التب لمراحل

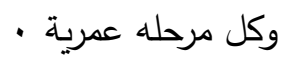

0ـ عمـل نــدوات ولقــاءات ومـؤتمرات دائهـة

لنشر الوعي بمفاهيم حوار الحضارات لدى

طلاب المراحل التعليميه المختلفة
1 - بناء قائمة بمفاهيم حوار الحضارات - باء

r- بناء تصور مقترح لمناهج التاريخ بالمرحلة

الثانوية فى ضوء مفاهيم حوار الحضارات

r- تطوير وحده تعليمية تفصيلية من التصور

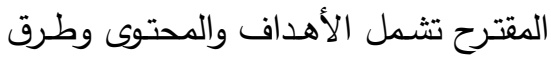

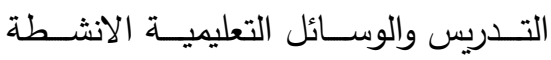

• ووسائل التقويم

ع - كانــت الوحـدة ذات فعاليــة عاليــة وأدت

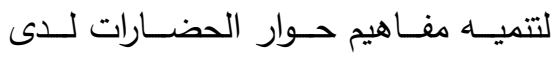

طلاب الصف الثاني الثانوي، من خـلال

وجـود فـروق ذات دلالــه احصـائية بـين

متوسط درجات طلاب المجموعة الظابطة

والتجريبية فى الاختبـار القبلي- البعدى

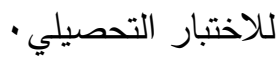

$$
\text { توصيات البحث }
$$

أوصت الدراسة الحالية بما يلي:

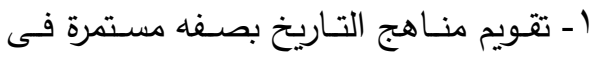

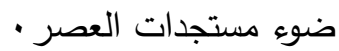

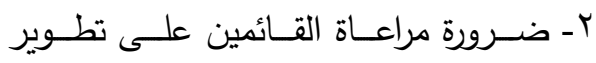

المنـاهج بـإدراج مفـاهيم حوار الحضـارات

بشكل جيد فى منـاهج التـاريخ بالمراحل

التعليميه المختلفة . 


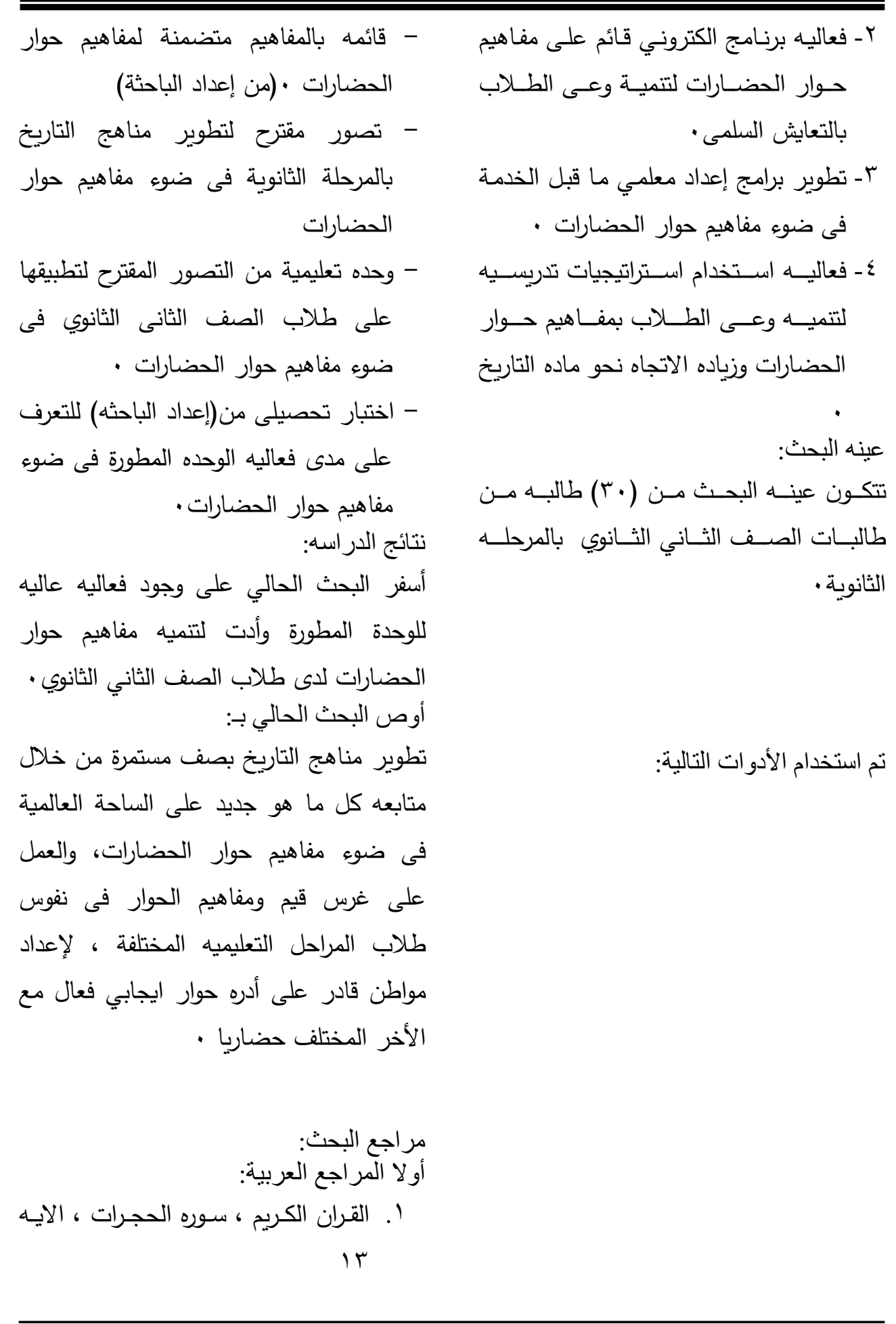




\begin{tabular}{|c|c|c|c|}
\hline \multirow{3}{*}{ 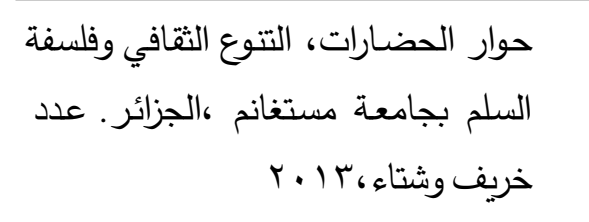 } & & 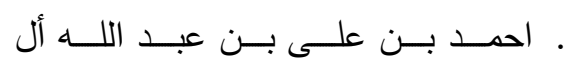 & $r$ \\
\hline & & 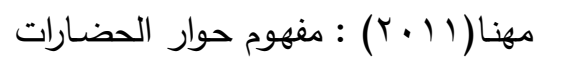 & \\
\hline & & ، جامعــه الإمــام محمـــــــن ســود & \\
\hline 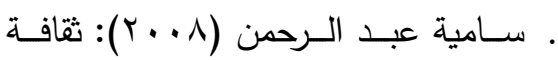 & 9 & الاســلاميه ، كليــه الثــريعة ، المملكــة & \\
\hline التواصل فـى عصـر العولمـة ، القـاهرة ، & & العربية السعودية، ماجستير ،رسالة غير & \\
\hline 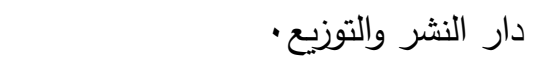 & & منشوره & \\
\hline . سـهيل فرح(9 . . r): حوار الحضـارات & 1 . & احمد كمال أبو المجد(ع ا • ץ): منتدى & $r$ \\
\hline المعنـــى والأفكــــار والتقتنيات، القــــاهرة & & الــوار الـوطني ،الكراسـة الثامنـة عشـر & \\
\hline ، المركز القومي للترجمه . & & (مســوليتي تجــاه حـوار مــع الأخـر )، & \\
\hline 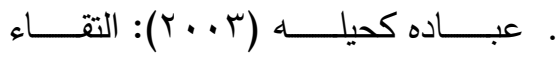 & 11 & مكتبه الاسكندريه · & \\
\hline الحضــارات في عـالم حـوار أم صـراع ، & & أميمـه عبود (^ . . r) : أسلوب الحوار & $\varepsilon$ \\
\hline القـــاهرة ، مركــز البحــوث والدراســات & & (الدوافع ، الأهداف ،الثروط، الآليات ، & \\
\hline الاجتماعيه. & & الأنماط) دمشق، البرامكه ، دار الفكر & \\
\hline عـلاء عبـــ اللــه مـراود(· ( • r) : اثـر & ir & 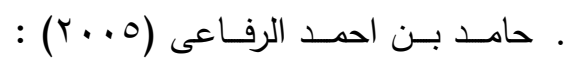 & .0 \\
\hline تدريس وحده مقترحسه في ضـوء مفهوم & & الإسلام ومنطلقات المشترك الحضـاري ، & \\
\hline حـوار الحضــارات في تتميـه مهـارات & & المنتـــى الاســلامى العـالمي للحــوار ، & \\
\hline 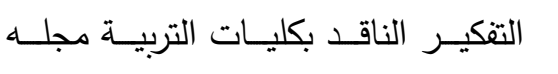 & & العـدد(r) الطبعـة الأولـى، إصـــارات & \\
\hline "الجمعيــــــة التزبويــــــة للدراســـــات & & 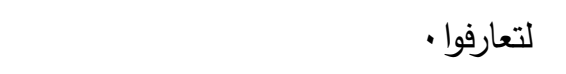 & \\
\hline الاجتماعيــة العــد الرابــع والعشــرين & & حسين حسن موسسى (1 (1) ب): حوار & .7 \\
\hline 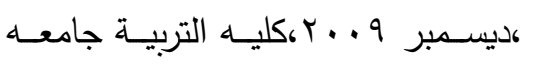 & & الحضـارات، رسـالة دكتوراه، القاهرة، دار & \\
\hline عين شمس ،القاهرة • & & الكتاب ألحديثه (منشوره كتاب) & \\
\hline 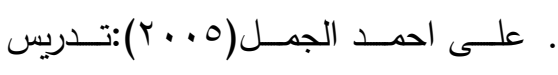 & .14 & رأفت منيب ( ( . . r): حوار الحضـارات & $v^{v}$ \\
\hline التـاريخ فـي القـرن الـــادي والعشـرين & & ، الأهــرام المســائي ، مكتبـــه الأهــرام & \\
\hline ،القاهرة ، عالم الكتب · . & & 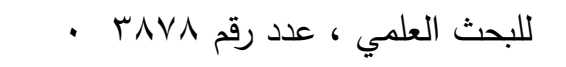 & \\
\hline 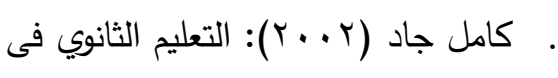 & $1 \leqslant$ & • زكي الميلاد (rا.ب): تعـارف &.$\wedge$ \\
\hline مطلع القرن الحـادي والعشرين ، القاهرة & & الحضـارات- الفكرة، الخبرة والتأسيس & \\
\hline ، دار قباء للطباعة والنشر والتتوزيع. & & ،مجلة الحوار الثقافي، تصدر عن مخبر & \\
\hline
\end{tabular}


22. Gholanali khoshroo(2013): dialogue among civilizations ,away to contain sectarian strife ,24,9,2012, Tehranpressenza Hong kong www.tran review.org

23. L. Groff(2002): intercultural communication ,interreligious dialogue and pace, original Research article futures ,v34, issue 8 ,october2002 pages(701-716)

24. Maritta stepanyant (2010): Is the dialogue between western and Islamic , social and Behavioral sciences 7299-7304

25. Michalis s.michael ,Fabio petito(2009): civilizational dialogue and world order ,plgrav macmillan.in the united ststes a division of st martinis press LL C,I new yourk

26. M.R Hafeznia(2007) :Dialogue among Civilizations as a new approach for international relations (tmu),vol21 no.1 pages 21,30, international journal.

27. Parliament of Malaysia2013: Dialogue of Civilizations 1, January, http://www.parlimen.gov.pdf

28. Sayed Mohammad Khatam(2012): Dialogue among civilizations "contexts and perspecting( unchronicle,( Vol.49 ISSUE3p-14p http://Data base ,Academic Search Complect.

29. Salah hashem mostafa abdelrazrk(2010):un learn in to lerence through education November 2010, IS secretary general association of arab universities the magazine of the united nations (un cgronicle), vol xl v11,no3.

30. Victor segesvary(2004): Dialogue of civilizations an introduction to civilizational analysis ,mikes international the hodue,Holland ,university press of America lanham ,Maryland, U.S.A

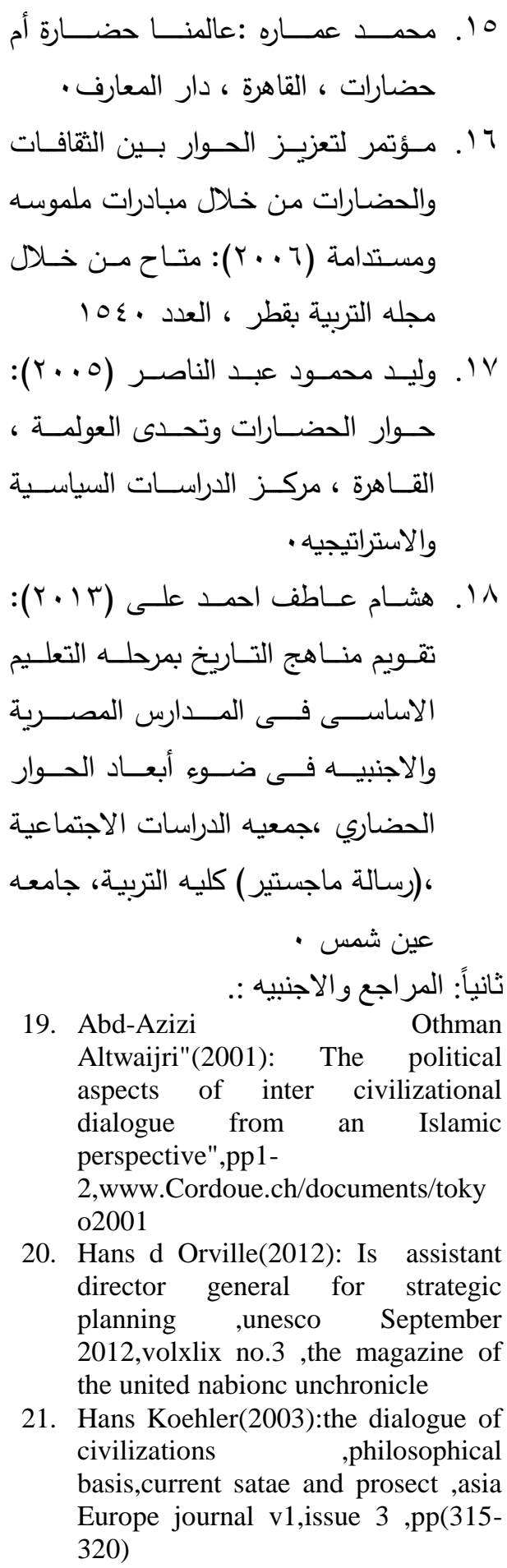

19. Abd-Azizi Othman Altwaijri"(2001): The political aspects of inter civilizational dialogue from an Islamic perspective",pp1-

2,www.Cordoue.ch/documents/toky o2001

20. Hans d Orville(2012): Is assistant director general for strategic planning ,unesco September 2012, volxlix no.3, the magazine of the united nabionc unchronicle

21. Hans Koehler(2003):the dialogue of civilizations ,philosophical basis,current satae and prosect ,asia Europe journal v1,issue 3 ,pp(315320) 


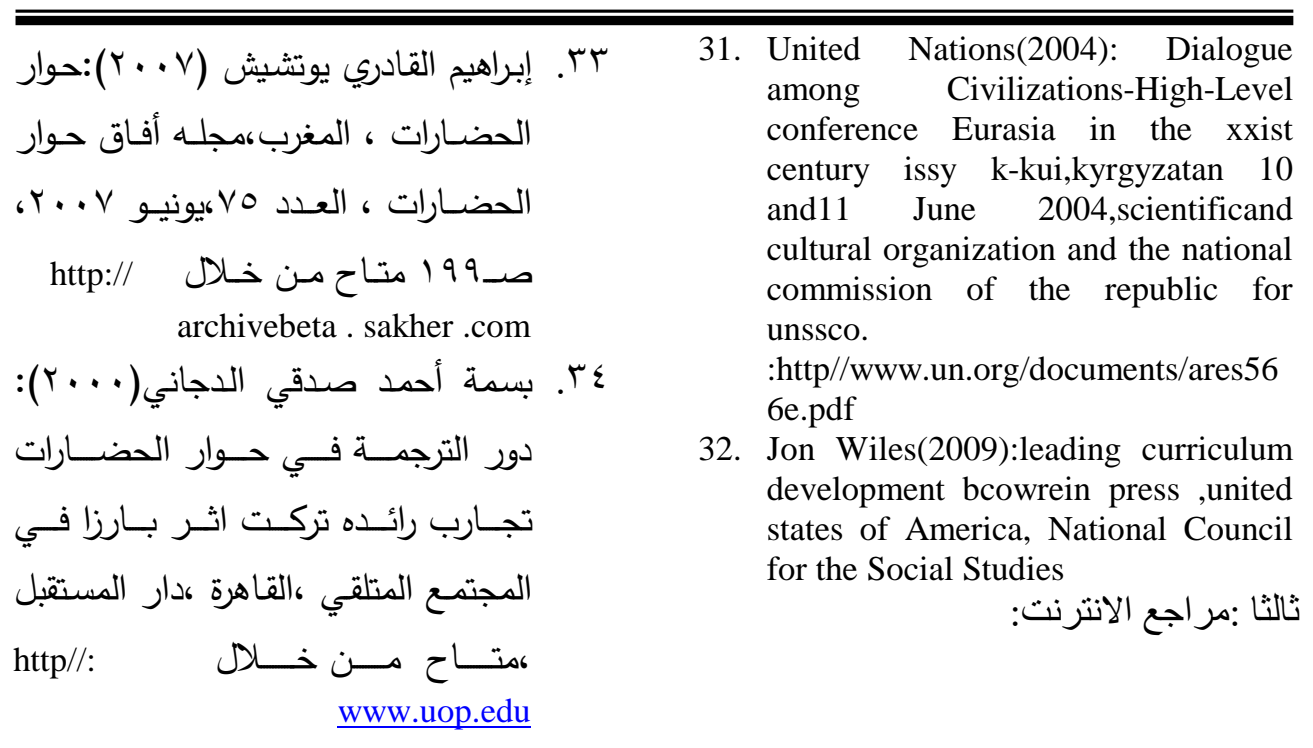

